\title{
Editorial: multifunctional cements and concretes
}

\author{
Leon Black
}

Senior Lecturer, Institute for Resilient Infrastructure, School of Civil

Engineering, University of Leeds, Leeds, UK

With a focus on multifunctional cements and concretes, this themed issue of Advances in Cement Research looks beyond conventional cements and concretes, looking at alternative applications and alternative binders. The seven papers in this themed issue span the incorporation of wastes into cementitious binders, the development of alternative binders, the use of carbon nano-tubes as integral sensors in concrete, and the development of self-healing cements and concretes. The papers recognise the incredible potential of cement and concrete to be more than 'just' structural materials, as ever showcasing the breadth of research in the field.

The first paper, by Suryanto et al. (2016), examines the selfhealing properties of engineered cementitious composites (ECCs). These composites are low water/binder ratio cement/ PFA blends containing chemical admixtures and then dosed with polyvinyl alcohol fibres. The ductile composites are designed to self-heal, and the study used ultrasonic pulse velocity measurements to determine the rate and extent of the self-healing capabilities of pre-loaded ECCs in the natural environment. The materials showed a great ability to self-heal, as evidenced by a return in ultrasonic pulse velocity values upon exposure to the external environment. This was ascribed to continued hydration and possible carbonate precipitation in microcracks.

The second paper, by Mas et al. (2016), looked at the potential re-use of a waste material, ceramic tile waste, within a cementitious matrix. The effective re-use of such a material would have environmental benefits, and also offer potential cost savings in construction, by replacing a more-costly material with a waste material. Using a range of microstructural techniques, the authors showed that replacement of cement with up to $35 \%$ of ceramic tile waste still yields a material with similar strengths to cement-fly ash blends.

The paper by Yilmaz et al. (2016) also looked at the incorporation of a waste material in cement, but this time they looked at the incorporation of wood particleboard wastes in cement clinker by the co-combustion of such materials with raw meal in a cement kiln. The replacement of raw meal by up to $100 \%$ particleboard waste was investigated, while replacement of up to $10 \%$ was found to have no discernible impact upon the performance of the resultant clinker.
Continuing on the theme of alternative silicate-based binders, Siauciunas et al. (2016) synthesised a cement with $\alpha-\mathrm{C}_{2} \mathrm{SH}$ as the principal binder. These binders have been of increasing interest in recent year (Stemmermann, 2010) and the authors present a means to increase the rate of binder formation upon hydrothermal treatment of the raw materials.

Progressing from the new to the slightly more developed alternative binder, Kaufmann et al. (2016) have investigated the thermal stability of calcium sulfoaluminate (CSA) cement pastes, supporting experimental data with thermodynamic modelling. Their results showed the rapid decomposition of CSA cements following steam curing, with potential implications for delayed ettringite formation. However, they then showed that heating under dry conditions led to the formation of meta-ettringite, and proposed that, under the right heating and drying conditions, the conversion could be used for heat storage.

Bernal et al. (2016) continue the theme of alternative binders by looking at the formation of alkali-activated binders. While sodium carbonate activation has been shown to be viable, and cheaper than the more conventional sodium silicate activated system, it had previously been shown to develop strength too slowly for many applications. By blending sodium carbonate and sodium silicate, the authors have obtained strengths similar to those obtained by sodium silicate activation, but with microstructures similar to those seen in sodium-carbonate-activated slag cements. Furthermore, this was obtained without the prolonged setting times associated with sodium-carbonate-activated systems, or without recourse to high temperatures.

The final paper in this themed issue is by Camacho-Ballesta et al. (2016), who have developed strain-sensing cement composites by the addition of carbon nanotubes (CNTs). The problem of CNT dispersion, a problem that bedevils many of the studies in the field, was overcome by a combination of chemical dispersants and ultrasonication. The piezoelectric properties of the CNTs allowed strain-sensing properties to be seen in cements of 14 days or older with CNT dosages of just $0.05 \%$. The authors suppose that such self-sensing systems 'are considered as a promising addition for practical applications such as structural health and load monitoring'. 
This issue is published alongside papers on the same theme in a soon-to-be-published issue of Magazine of Concrete Research. The papers include a paper on the stability of foamed concrete (Jones et al., 2016), one on the properties of concrete contained flue gas desulferisation waste (Khatib et al., 2016), and one on carbon dioxide pricing (Black and Purnell, 2016).

As ever, it's been a pleasure to read these papers when preparing this editorial. I hope that you find the papers equally informative.

\section{REFERENCES}

Bernal SA, San Nicolas R, van Deventer JSJ and Provis JL (2016) Alkali-activated slag cements produced with a blended sodium carbonate/sodium silicate activator. Advances in Cement Research 28(4): 262-273; http://dx.doi.org/10.1680/ jadcr.15.00013.

Black L and Purnell P (2016) Is carbon dioxide pricing a driver in concrete mix design? Magazine of Concrete Research, http://dx.doi.org/10.1680/jmacr.15.00018.

Camacho-Ballesta C, Zornoza E and Garcés P (2016) Performance of cement-based sensors with CNT for strain sensing. Advances in Cement Research 28(4): 274-284; http://dx.doi.org/10.1680/jadcr.14.00120.

Jones MR, Ozlutas K and Zheng L (2016) Stability and instability of foamed concrete. Magazine of Concrete Research, http://dx.doi.org/10.1680/macr.15.00097.
Kaufmann J, Winnefeld F and Lothenbach B (2016) Stability of ettringite in CSA cement at elevated temperatures. Advances in Cement Research 28(4): 251-261; http://dx.doi. org/10.1680/jadcr.15.00029.

Khatib JM, Mangat PS and Wright L (2016) Mechanical and physical properties of concrete containing FGD waste. Magazine of Concrete Research, http://dx.doi.org/10.1680/ macr.15.00092.

Mas MA, Monzó J, Payá J, Reig L and Borrachero MV (2016) Ceramic tiles waste as replacement material in Portland cement. Advances in Cement Research 28(4): 221-232; http://dx.doi.org/10.1680/jadcr. 15.00021.

Siauciunas R, Baltakys K, Gendvilas R and Prichockiene E (2016) Synthesis of low-energy cement based on $\alpha-\mathrm{C}_{2} \mathrm{SH}$. Advances in Cement Research 28(4): 241-250; http://dx.doi. org/10.1680/jadcr.15.00024.

Stemmermann P, Schweike U, Garbev K, Beuchle G and Möller H (2010) Celitement - a sustainable prospect for the cement industry. Cement International 8(5):52-66.

Suryanto B, Wilson SA, McCarter WJ and Chrisp TM (2016) Self-healing performance of engineered cementitious composites under natural environmental exposure. Advances in Cement Research 28(4): 211-220; http://dx.doi. org/10.1680/jadcr.15.00022.

Yilmaz M, Tokyay M and Yaman 10 (2016) Cement production by cement-bonded wood particleboard wastes. Advances in Cement Research 28(4): 233-240; http://dx.doi.org/10.1680/ jadcr.15.00023. 